\title{
The "Spirits" of Terrorism and (Digital) Insecurity in the Global Pandemic Era
}

\author{
Giacomo Buoncompagni \\ Correspondence: Giacomo Buoncompagni, University of Macerata, Department of Political Science, Communication \\ and International Relation, Italy.
}

Received: September 8, 2020

Accepted: September 29, 2020

Online Published: October 14, 2020

doi:10.11114/ijlpa.v3i2.5045

URL: https://doi.org/10.11114/ijlpa.v3i2.5045

\begin{abstract}
The Coronavirus pandemic and the anti-contagion restrictions adopted by governments around the world, as well as the strong media representations of the disease and deaths in hospitals have meant for many vulnerable and at risk subjects (the elderly, women, children, immigrants), already victims of violence, an aggravation of their personal problems. Some people have faced a double fear and a double enemy: Covid 19 on the outside and the context of unease and violence in which they live from the inside. According to a United Nations report, the forced quarantine that has forced tens of millions of people into their homes for weeks has caused an increase in abuse and violence against the most vulnerable people. The stress of the quarantine and the uncertainty of losing one's job have also worsened due to the tensions linked to economic uncertainties and the pandemic. The result: increased global tension and insecurity, increased cases of social injustice and the awakening of some forms of symbolic and political violence, also visible in digital environments. The following document will explore some cases mainly related to social and digital (in) security, terrorism in today's health emergency and the idea of a pandemic as a cultural trauma.
\end{abstract}

Keywords: cyber violence, digital media, pandemic, web, terrorism

\section{Introduction}

The Covid-19 pandemic has increased levels of insecurity and violence against women, children, the elderly and minorities worldwide and, without targeted government attention, risks exacerbating gender inequalities and levels of discrimination.

This is the warning launched by a guide presented by Amnesty International, Women's Link Worldwide and the International Planned Parenthood Federation.

During this health crisis and in the aftermath of the Covid-19 pandemic, people's rights must be respected and guaranteed," said Viviana Waisman, President and CEO of Women's Link Worldwide.

It is necessary to demand that European states respect their obligations and maintain their commitment to the rights and lives of the most fragile. Insecurity has increasingly emerged from the digital environment with high cases of misinformation and health data theft, followed by violence and terrorist attacks.

\section{The State of Health of Cyber-Security}

With the digital revolution, health care has become one of the most important sectors, capable of hosting innovation and technology, new forms of communication and assistance 2.0, but, at the same time, we record a high number of cyber attacks.

The consequences can be relevant in terms of patient welfare, as, in the majority of cases, cyber-criminals demand a real ransom and act by blocking access to data or reselling the data to the black market of the deep web, the dark side of the Net.

There are two types of cyber-attack generally used: the "seizure" of data and infrastructure that are rendered unreadable and unusable and the other, the theft of personal data (including medical records).

This happens because seizing information of this nature translates, for social-health structures, into the impossibility of providing their services and therefore putting people's health and life at serious risk.

In January 2017, the Health Ministers of the OECD (Organisation for Economic Cooperation and Development) 
countries called on member states to adopt a system of common rules allowing health data to be used and re-used for purposes of public interest while fully respecting people's privacy.

The "Recommendation on Health Data Governance" was adopted by the OECD Council on 13 December 2016, but was only made public after its approval by the relevant Ministers at the meeting in Paris.

The aim of the document was to offer useful indications to improve and make the health system in the member countries of the organisation more efficient, encouraging the creation of a shared platform for the correct management of health data processed for public health, for statistical and scientific research purposes, as well as for the provision of the services offered.

The OECD believes that, if well implemented in the respective countries, the indications will also contribute to improving the quality of health care and, consequently, to developing a "healthy" society.

However, these objectives will have to be pursued by promoting and protecting the individual freedoms and the protection of the sensitive personal data of those who use health services.

At the present time, in the midst of a health and economic crisis, Ursula von der Leyen, President of the European Commission, recently pointed out that cybercrime in the EU is constantly increasing due to the coronavirus epidemic.

Cybercriminals are taking advantage of the increasing amount of time people spend online due to new measures taken by Member States to stop the spread of the virus.

"They follow us online and exploit our concerns about the coronavirus. Our fear becomes their business opportunity," von der Leyen said in a video message (24 March 2020).

As a result, the police agency Europol is fighting the trafficking of counterfeit coronavirus "medicines" and at the same time, Internal Market Commissioner Thierry Breton is consulting telecoms operators on how to protect EU networks from cyber attacks.

The European Cyber Security Incident Response Team (CSIRT) has also raised the alert level and is calling for strong cyber-resilience during this specific period as a form of strategic crisis response.

In the meantime, more and more hospitals, research centres and medical centres are being targeted by organised IT units seeking information, intelligence and system accessibility.

According to Lukasz Olejnik, an independent cyber security researcher and consultant who analysed this phenomenon, today's unexpected and extraordinary measures increase cyber risk in many ways we have never seen before,

The coronavirus crisis is sadly tempting for exploitation because people might be easier to cheat using the" coronavirus theme "because now everyone knows about it.

The World Health Organization (WHO) has recently alerted citizens and institutions to the possibility of receiving fake news, suspicious e-mail messages trying to exploit the Covid-19 emergency to extort money and sensitive data.

It is no coincidence that attempts to piracy the information systems of the WHO, in particular, and its partners, have increased a few days after the official declaration of a global pandemic.

Although the objective of these attacks is not always so clear, one could assume a multitude of reasons for attacking important health organisations during this pandemic.

For example, cybercriminals could be looking for information on coronavirus-related treatments, tests or vaccines to sell on the black market, encrypt sensitive data and store it for ransom, or simply disrupt the institution's operations.

Techniques seen since the beginning of the year include bogus emails with links claiming to have important updates, which once clicked on lead to infected devices.

These phishing attempts have been observed in several countries and can lead to the loss of money and sensitive data; they are versatile attacks and can be conducted through various media and techniques, adapted to different sectors and monetised with multiple tools, including ransomware, credential theft, bitcoin or fraud.

Two aspects emerge from this scenario: the first concerns national security.

In this historical phase it is necessary to invest in health and safety, which means rethinking European budgets to devote strategic resources to research, development and training, becomes crucial for the future.

\section{Coronavirus as Cultural Trauma}

The new Coronavirus pandemic and the following restrictive measures activated, the information overload, the high number of victims and the poor results achieved so far in terms of scientific research in finding a vaccine capable of eradicating covid-19 are all elements that have disrupted the daily life of every single citizen globally. There is no doubt 
that the numerous deaths, the communicative confusion, the late intervention by national and European institutions, the lack of a cure, the health crisis first and then the economic crisis are factors that have seriously affected the private and professional life of each individual. But how this unexpected crisis and emergency situation is exactly perceived and how such configurations affect collective daily life in the "new normality" has not yet been sufficiently conceptualised.

People need security, affection, order and connection, but when something happens that puts at serious risk the total satisfaction of these needs, individuals risk being traumatized.

According to what Alexander (2012) defines as "profane theory of trauma", the latter can be defined as a naturally occurring event capable of shattering the sense of well-being of an individual and collective actor; "being traumatized" is the impulsive and immediate response to such a destructive event.

Psychoanalytic and enlightenment approaches see traumatic events as a sudden shock, a blow to the human psyche, a fact that is perceived, but unconsciously, distorted in the imagination and individual memory. It is not so much factors such as the unpredictability or danger of a real or imaginary phenomenon that determine the trauma, but rather the public representation of those events as unforeseen facts and dangerous for the collective identity.

Every political or moral ruling class must take into account a problem, a crisis, an emergency and take action to solve it, every society produces dysfunctional or pathological conditions in its own way; the socio-cultural process, which defines the trauma status, is strongly influenced by the power structures and the sensitivities and competences of the social actors involved.

The collapse of a country's economy, a natural catastrophe, as well as an epidemic, can undoubtedly be classified as events that could lead to the emergence of important crisis situations within an entire country or a continent, but despite the state of reality of such events, they do not necessarily become traumatic for the affected communities.

In order for a trauma to emerge at the level of the community, social crises must change into cultural crises.

A cultural trauma occurs when members of a community feel that they have been affected by a traumatic event that has left an indelible mark on their group consciousness (Alexander, 2012).

The Lancet medical journal on the psychological impact of quarantine, investigating the psycho-social consequences of groups of individuals locked indoors to prevent the spread of a contagion, in situations similar to the one currently underway, pointed out that many individuals have shown post-traumatic symptoms of stress, insomnia, anxiety, irritability, sometimes depression. In general, the dominant feelings are anger and confusion.

What we define "trauma", in the common sense, refers to something "commonly experienced and intuitively understandable" (Alexander, 2012), but in reality this is the product of an articulated work of social production of meaning called "spiral of meaning". What becomes traumatic for the community is not only the event, but its representation. It is a real symbolic operation, in a sense, simply "telling a story" where the victim affected by the trauma tries to convince wider and wider audiences, starting from the carrier group to reach wider audiences, and in some cases entire societies, to have been affected in the same way by the same event, often promoting the creation of a polarized and fragmented public sphere.

The process of trauma can be defined as the distance separating an event from its representation; Thompson (1998) speaks of a "process of representation" or "spiral of signification" that includes four dimensions that we could, in our case, apply to the current emergency situation:

-nature of pain: What really happened with the covid-19?

-nature of victims: Which group was affected by the virus?

-relation between trauma victims and audience: Who listens to the victims' stories and how people in front of the TV identify with the patients?

-attribution of responsibility: Who caused the virus, how can it turn into trauma, how do we overcome the emergency?

Each of these dimensions, as well as the process of representation itself, is strongly linked to the mediation action of the so-called "institutional arenas" and hierarchies of stratification.

The scientific arena, for example, is the place of debate on the nature and dangerousness of the virus, just as the mass-media arena is the space of the infodemia, of the information overload on the current disease and author of numerous institutional conflicts; then there is the arena of the state bureaucracy that in the case in point has slowed down the arrival of funding to support Italian families and businesses, as well as the obtaining of health instruments (masks, gloves...) useful for personal defence and to face the health and economic crisis. 


\section{4. (Health)Terrorism and the "Spirit" of Violence}

On a normal Friday, September 25, 2020, four people were injured with a stab wound in Paris, right near the now former editorial office of Charlie Hebdo; the attack was carried out by an 18-year-old Pakistani, already known to the police for common crimes. A violent action connected, as confirmed by the French government and intelligence, to the people of Saïd and Chérif Kouachi, authors of the attacks of 7 January 2015 in the very editorial office of the satirical newspaper Charlie Hebdo in response to the publication of the cartoons depicting the Prophet Mohammed, and the attack on 9 January of the same year in the kosher restaurant of the same year at the hands of jihadist Amédy Coulibaly who left a pre-recorded video of the attacks, reiterating the belligerent logic of those killings compared to what France was doing against the Islamic State.

In those cases 17 deaths were recorded among members of the newspaper's editorial staff, policemen and supermarket clerks.

In the COVID-19 obsessed news cycle and in political agendas around the world similar stories about terrorism and terrorist attacks seemed to have largely disappeared. Paradoxically long before the current pandemic, the language of epidemiology had proved useful in understanding by analogy how terrorism works as a phenomenon that depends on contact and social exchange and rapidly expands opportunistically when defences are lowered.

In these months of global emergency there is certainly good news (useful to underline here): the curve of international terrorist attacks has actually been flattened, as having lost its "Physical Caliphate", the Islamic State seems to have lost its ability (and perhaps willingness) to launch attacks around the world well beyond the conflict zones.

But in spite of the historical moment of health and economic crisis that has hit the whole of humanity, in which the attacks seemed to have been culturally and cognitively "removed" because of the Covid-19, the jihadist front nevertheless appealed to strike the West and to take advantage of the pandemic period and the political-economic chaos present in most European countries (UN, 2020). On the other hand, terrorism has always found in times of crisis new opportunities to promote its objectives and the coronavirus, causing thousands of deaths, the collapse of the global economy and a socio-political upheaval, it cannot be denied that it has triggered an international crisis.

In order to understand possible signs of return after periods of medium-long "pause", in the middle of an ongoing pandemic, it is important first of all to contextualize the terrorist phenomenon and understand the "spirit" that animates it.

First of all, the form that Islamist jihad gives to terrorism in the contemporary world paradoxically unites two distinct and contradictory inspirations: that of traditional and that of modernity. The violent act we witnessed last Friday is nothing new in today's societies and has nothing specifically Islamic, Oriental or Arabic about it, but has a specific and ever-present trait, that of violence (which goes beyond the media label of "madness"), that of dominion over the other and the will of men to kill their own kind, accepting, if necessary, that they must die themselves.

It is therefore pointless to pretend to find exclusively in the religious register a scenario that would allow us to quickly emerge from this historical-cultural crisis, but at the same time it would be wrong to fall into the errors of a certain thought in which great intellectuals have tried to explain that the real cause of terrorism is not to be found in religion, but in the resistance of the oppressed to Western imperialism. It is useful, in fact, to begin to distinguish Islam from fanaticism, which is capable of nourishing and creating institutional networks of collaboration with Muslims who fight fundamentalism, defined by Abdelwahab Meddeb (2002), the "disease of Islam". Since globalization is not only economic and political, but also cultural, this implies that religions themselves, like cultures, civilize each other through dialogue among themselves and with the secularized world (Appadurai 2005; Bastenier 2015).

Only by making this distinction and recognising both positions as "valid" can terrorism be hindered while at the same time identifying the limits of current securitarian policies. In order to meet these aims, political leaders are confronted with a twofold need: to distinguish the facts that have actually happened and their perception in the collective imagination and then to face public opinion by managing insecurity and fears of possible anti-democratic implications in repressive action.

Starting from the fact that an idea of a $100 \%$ effective anti-terrorist policy does not exist, institutions should recognize the limits of the Hobbesian imperative, accepting and admitting (even publicly) that we must not give in to authoritarian drifts harmful to democracy, and remember that one of the main objectives of terrorism is to undermine the trust that all citizens have in the guarantor authority of the political community, casting a priori suspicion on entire categories of population that we claim to want to integrate into our societies.

In this regard, it should not be overlooked that the social and economic impacts of COVID-19 have had the right potential to undermine social cohesion and fuel conflicts between groups and forms of exclusion against minorities, thus creating the conditions for the spread of terrorism and violent extremism (Barton, 2020). 
Terrorists are exploiting the hardship, uncertainty and economic difficulties caused by COVID-19 to spread fear, hatred and division, to radicalize and recruit new followers. While governments around the world are focused on fighting the virus (and some have even announced the re-allocation of resources, including the withdrawal of foreign armed forces involved in operations against ISIS and al-Qaeda and the relocation of armed forces to support relief efforts in the event of an internal pandemic), the Islamic State and al-Qaeda have adapted to the new context of the crisis and aim to re-emerge online and offline, urging followers and affiliates to intensify attacks (ICG, 2020).

The pandemic has highlighted the vulnerability of institutions and ordinary citizens to new violent extremist narratives favouring terrorism and emerging forms of terrorism, including cyber attacks against health institutions; deadly global threats such as terrorism and COVID-19 now require the European institutions to plan a common operational strategy, but first and foremost a renewed sense of unity and solidarity.

The United Nations defines it as "highly probable" that terrorist threats will continue to diversify, underlining the possibility of attacks that will result in the disruption of critical infrastructure, the use of biological agents and incitement to hatred, particularly in the digital public space, now a "familiar and professional" environment for most globally connected audiences engaged in consuming any form of media product.

Therefore, two aspects emerge from the scenario described: the first concerns national security and the safeguarding of democracy in the pandemic.

In this historical phase it is necessary to invest in public communication, health and safety, this means rethinking European budgets to dedicate strategic resources to research, training, and the development of counter-narratives to combat violence and disinformation, interventions that are crucial for the future.

The real strategy to resist pandemic attacks lies in logistics, or rather, in having and obtaining more hospitals, beds, specialists, nurses, machinery and medicines, the one to prevent (and reduce) the possibility of terrorist attacks lies in the existence of non-obstructive social imagery, free and militant opinions, even contradictory ones, without self-censorship and in knowing how to guide (and judge) a democracy, not according to its enemies, but to its results, without giving in to the logic of repression.

The second aspect concerns the level of collaboration and trust between the media, citizens (native and foreign) and local, national and European institutions.

Communicating in a correct and orderly way crises and possible contrast actions, accepting restrictions and consciously participating in their application, encouraging forms of "hospitality" and openness to the Other, developing relationships in the context of proximity avoiding any form of etiquette and exclusion, are all useful elements to achieve the desired result: defeating the virus and limiting any form of threat and social conflict to (re)build the future.

Moreover, suggests Bastenier (2015), in order to restore or strengthen trust in institutions and collaboration within each community and to monitor the "spirit" of terrorism, especially in a historical period of full health emergency in progress, it is important to encourage the emergence of new forms of "political creativity" in democracies, where the need to redefine oneself is constant and the alternative would be to get lost in the logic of policing and chaos caused by situations of strong crisis.

\section{Conclusion}

After what has been highlighted, it is impossible not to underline how the emergency situation caused by Covid -19 in the first months of the year 2020, has put the mobility phenomenon in crisis and highlighted the need to guarantee new strategies of cultural integration that respond to the diversified needs of the territory.

Among the most complex challenges that institutions had to face as a result of the emergency was to communicate the emergency and get directly to publics, such as migrants and refugees, to avoid the risk of exclusion and social-technological discrimination.

Restrictive measures and the closure of borders have obscured for many months that minimum debate on the issue of humanitarian corridors, giving way to that of tourist corridors, highlighting the issue of the "right to mobility", within which migration and tourism occupy the same space, ignoring the existence of a "right to migrate"; in this way the invisibility of some categories (such as irregular migrants and minors) and inequalities both from an economic and labour relations point of view have gradually increased.

The health crisis has also represented a risk factor for the health of migrant populations in Europe, not only with respect to the possibility of coming into contact with the virus, but also for the possible negative health outcomes linked to barriers in access to health and communication services.

A particularly high risk has affected all those who live in crowded conditions, with difficulties in self-isolation and social distancing (e.g. in immigration reception centres), or in poor hygiene conditions and with reduced access to clean 
water. Moreover, migrant groups and minorities differ in their access to knowledge and information about COVID-19 and some may lack the social, economic or technical means (such as access to the Internet) to take care of themselves and their families during isolation.

\section{References}

Alexander, J. (2012). Trauma. A Social Theory, Polity Press.

Appadurai, A. (2005). Sicuri da morire, Meltemi, Milano.

Barry, C. (1997). The Future of CyberTerrorism. Proceedings of 11th Annual International Symposium on Criminal Justice Issues, The University of Illinois at Chicago.

Bastenier, A. (2015), L’espirit du terrorisme, La Revue nouvelle, 8, 22-35.

Boyd, D. (2014). It's complicated. La vita sociale degli adolescenti sul web, Lit Edizioni, Roma.

Buoncompagni, G. (2018). Forme di comunicazione criminologica, Aras ed. Fano.

Buoncompagni, G. (2020). L'immigrazione tra media tradizionali e social network: la narrazione del pregiudizio nella dimensione culturale e comunicativa. Atti della IV Conferenza Nazionale delle Dottorande e dei Dottorandi in Scienze Sociali, Sapienza.

Buoncompagni, G., \& D’Ambrosi, L. (2020). Hate Speech Towards Migrants, in La Rocca G. Torvisco J.M., (a cura di). Technological and Digital Risk: Research Issues. Peter Lang Publishing, pp. 177-190.

Cipolla, C. (2012). La devianza come sociologia, Franco Angeli, Milano.

Codeluppi, V. (2015). Mi metto in vetrina. Selfie, Facebook, Apple, Hello Kitty, Renzi e altre vetrinizzazioni, Mimesis edizioni, Milano.

Codeluppi. (2010). Persuasi e felici?, Carrocci, Roma.

Cohen, K. A. (1963). Ragazzi delinquenti, Feltrinelli, Milano.

Colarik, A. M. (2007). Cyber Warfare and Cyber Terrorism, IGI Global, Hershey. https://doi.org/10.4018/978-1-59904-021-9.ch003

Collins, R. (2008). L'intelligenza sociologica. Un'introduzione alla sociologia non ovvia, Ipermedium libri, Napoli.

Collins, R. (2014). Violenza, Un'analisi sociologica, Rubettino editore, Catanzaro.

Corradi, C. (2009). Sociologia della violenza, Meltemi editore, Roma.

Couldry, N. (2015). Sociologia dei nuovi media, Pearson, Milano-Torino.

D’Andria, P. (2003). Regime detentivo e sistemi di garanzia. Ordinamento penitenziario e regolamento interno. Strumenti di trattamento in Corso di formazione per assistenti volontari penitenziari, Livorno.

Dalfonzo, V. (2002). National crisis negotiation course, FBI Academy, Quantico, Virginia.

De Vincentiis, M. (2010). Comunicare l'emergenza, Centro di Documentazione Giornalistica.

Decker, Scott, H., \& Pyrooz, C. D. (2015). The handbook of gangs. Chichester, West Sussex: Wiley-Blackwell. https://doi.org/10.1002/9781118726822

Dilts, R. (2013). Il potere delle parole, Alessio Roberti Editore - Nlp Italy, Milano.

Donato, F. (2006). Criminalistica e tecniche di investigazione, Olimpia, Firenze.

Freedman, D., Thussu Daya, K. (2012). Media and Terrorism:Global Perspectives, SAGE Publishing, New York. https://doi.org/10.4135/9781446288429

Gallino, L. (1993). Dizionario di Sociologia, UTET, Torino.

Gatto, T. C. (1994). Le sette in Italia, Newton s.r.l., Roma, 1994.

Gerber, G. (1971). Violence in Television Drama: Trends and Symbolic Functions, in G.A. Comstok and E.A. Rubistein, Television and Social Beavihour, Washington, D.C. U.S. Government Printing Office, 1971.

Goffman, E. (2003). Le Istituzioni totali : i meccanismi dell'esclusione e della violenza, Einaudi ,Torino.

Jamenson, F. (1998). The culture of globalization, Duke University Press Books.

Jenkins, H. (2007). Cultura convergente, Apogeo Milano.

Jenkins, H., Ford, S., \& Green, J. (2013). Spreadable media. I media tra condivisione, circolazione, partecipazione, Apogeo Education, Milano. 
Laqueur, W. (1978). Storia del terrorismo, Rizzoli, Milano.

Lever, F., \& Mantovani, M. (2013). Tra silenzi e parole. Percorsi di comunicazione, Ed. Las, Roma.

Lewis, M. (2005). Il sé a nudo, Giunti Gruppo Editoriale, Firenze.

Lorusso, P. (2011). L'insicurezza nell'era digitale, Tra cybercrimes e nuove frontieree di investigazione, Franco Angeli, Milano.

Marotta, G. (2004). Tecnologie dell'informazione e comportamenti devianti, LED Edizioni, Milano.

Marotta, G. (2015). Profili di criminologia e comunicazione, Franco Angeli, Milano.

Mastronardi, V. M. (2012). Manuale di comunicazione non verbale, Carocci, Roma.

McLuhan, M. (2008). Gli strumenti del comunicare, Il Saggiatore,Milano.

Meltzer, B. N., Petras, J. W., \& Reynolds, L. T. (1980). L'interazionismo simbolico, Franco Angeli, Milano.

Meluzzi, A. (2014). Crimini e mass media, Infinito edizioni,Formigine (MO).

Meluzzi, A. (2015). Bullismo e cyber bullismo, Imprimatur ed., Reggio Emilia.

Menduni, E. (2009). I media digitali, Ed. Laterza, Bari.

Miller, W. (1958). Lower Class Culture as a Generating Milieu of Gang Delinquency. Journal of Social Issues, 14(3), 5-20. https://doi.org/10.1111/j.1540-4560.1958.tb01413.x

Morin, E. (2015). Etica e identità umana. Meet media guru, Egea, Milano.

Neisser, U. (1993). Conoscenza e realtà, Il Mulino, Bologna.

Noesner, G. W., \& Webster, M. (1997). Crisis intervention: Using active listening skills in negotiations. FBI Law Enforcement Bulletin. https://doi.org/10.1037/e317052004-003

Orsini, A. (2010). Anatomia delle Brigate Rosse, Rubettino, CZ.

Orsini, A. (2015). La Fortuna del ISIS, Papeles FAES Foundación para el Análisis y los Estudios Sociales, 181.

Paccagnella, L. (2010). Sociologia della comunicazione, Il Mulino, Bologna.

Padula, M., \& Cerretti, F. (2016). Umanità mediale. Teoria sociale e prospettive educative, ETS edizioni, Pisa.

Palermo, V., \& Mastronardi, M. (2005). Il profilo criminologico, Giuffrè editore, Milano.

Petrone, L., \& Troiano, M. (2008). Dalla violenza virtuale alle nuove forme di bullismo, strategie di prevenzione per genitori, insegnanti e operatori, Ed. Magi, Roma.

Pisano, V., \& Piccirilli, A. (2005). Aggregazioni terroristiche contemporanee, Adkronos libri, Roma.

Pollitt, M. (1997). A Cyberterrorism Fact or Fancy?, Proceedings of the 20th National Information Systems Security Conference, 1997, pp. 285-289.

Ponti, G., \& Merzagora, I. (2008). Compendio di criminologia, Cortina Editore, Milano.

Raffagnino, R., \& Occhini, L. (2004). Il corpo e L'Altro, Edizioni Angelo Guerini Associati SpA, Milano.

Regoliosi, L. (2005). La prevenzione del disagio giovanile, Carocci, Roma.

Watzlawick, P., \& Jackson, D. D. (1971). Pragmatica della comunicazione umana, Casa Editrice Atrolabio-Ubaldini Editore, Roma.

White, J. R. (2013). Terrorism and Homeland Security, Cengage Learning, Stanford.

Womer, S., \& Bunker, R. J. (2010). Surños Gangs and Mexican Cartel Use of Social Networking Sites. Small Ways and Insurgencies, 21, 81-94.Young S. K. (2000), Presi nella Rete, Intossicazione e dipendenza da Internet, Calderini editore, Milano. https://doi.org/10.1080/09592310903561486 


\section{General sithography}

[1] Link: https://sicurezza.net/dati-trend/nel-2019-cyber-attacchi-per-due-terzi-delle-aziende-del-settore-sanitario

[2] Link: https://www.privacy.it/2017/01/26/ocse-rispettare-la-privacy-nellutilizzo-dei-dati-sanitari/

[3] Link: https://www.tgcom24.mediaset.it/mondo/coronavirus-von-der-leyen-in-aumento-i-medicinali-contraffatti_165 16899-202002a.shtml

[4] Link https://www.agendadigitale.eu/sicurezza/cybersecurity-che-significa-la-resilienza-cuore-della-nuova-strategiaue/

[5] Link: https://www.cybersecurity360.it/nuove-minacce/coronavirus-in-aumento-campagne-di-phishing-e-malspam-atema-covid-19-consigli-per-difendersi/

[6] Link: https://tg24.sky.it/tecnologia/2020/03/06/coronavirus-oms-email.html

\section{Copyrights}

Copyright for this article is retained by the author(s), with first publication rights granted to the journal.

This is an open-access article distributed under the terms and conditions of the Creative Commons Attribution license which permits unrestricted use, distribution, and reproduction in any medium, provided the original work is properly cited. 